\title{
PERANCANGAN FASILITAS KERJA DAN PERBAIKAN POSTUR KERJA PADA AKTIVITAS MANUAL MATERIAL HANDLING KARYAWAN TOKO MEGA MAS ELEKTRONIK MAKASSAR.
}

\author{
$\operatorname{Arminas}^{1}$ \\ Jurusan Teknik Industri Agro, Politeknik ATI Makassar \\ Jl. Sunu No. 220 Makassar \\ Email : arminas.atim@yahoo.com
}

\begin{abstract}
Abstrak
Aktivitas penanganan material secara manual (Manual Material Handling) yang terdiri dari mengangkat, menurunkan, mendorong, menarik dan membawa merupakan sumber utama keluhan karyawan di industri. Peranan manusia sebagai sumber tenaga kerja masih dominan dalam menjalankan proses produksi terutama kegiatan yang bersifat manual. Sikap kerja dalam mengangkat beban seperti yang dilakukan oleh karyawan Mega Mas Elektronik Makassar tergolong belum ergonomis, seperti pada saat mengangkat beban (kulkas) seberat $35 \mathrm{~kg}$ dengan posisi tangan memanjang ke atas dengan punggung sebagai tumpuan beban yang apabila aktifitas ini dilakukan secara berulang dapat menyebabkan keluhan pada punggung dan bagian siku karyawan, kesalahan-kesalahan dalam mengangkat beban tersebut dapat mempengaruhi produktifitas kerja karyawan. Tujuan penelitian ini adalah (1) Untuk mengidentifikas kondisi postur kerja dalam melakukan aktivitas pemindahan material pada Toko Mega Mas Elektronik Makassar. (2) Untuk menganalisis dan membuat rancangan fasilitas kerja yang lebih ergonomis menggunakan analisis RULA, serta untuk meningkatkan efektivitas kerja dari karyawan. Jenis penelitian yang dilakukan adalah penelitian deskriptif yang dilakukan dengan membuat gambaran atau deskriptif tentang suatu keadaan secara objektif. Metode penelitian deskriptif ini digunakan untuk menjawab permasalahan penilaian postur kerja pada devisi kulkas Toko Mega Mas Elektronik. Berdasarkan hasil pengolahan data dengan metode RULA maka dapat disimpulkan bahwa postur kerja pada bagian. mengangkat kulkas berada pada level resiko 3, yang mengindikasi investigasi dan perubahan postur kerja harus dilakukan secepatnya. Sedangkan kegiatan membawa dan meletakkan kulkas digudang berada pada level resiko 4 yang berarti investigasi dan perubahan postur kerja harus dilakukan segera.
\end{abstract}

Kata kunci :

Manual Material Handling, RULA, kulkas, postur kerja, fasilitas kerja, ergonomis.

\section{A. Pendahuluan}

Peranan manusia sebagai sumber tenaga kerja masih dominan dalam menjalankan proses produksi terutama kegiatan yang bersifat manual. Salah satu bentuk peranan manusia adalah aktivitas pemindahan material secara manual (Manual Material Handling/MMH). Kelebihan $\mathrm{MMH}$ bila dibandingkan dengan penanganan material menggunakan alat bantu adalah pada fleksibilitas gerakan yang dapat dilakukan untuk beban-beban ringan. Akan tetapi aktifitas manual material handling dalam pekerjaan-pekerjaan industri banyak diidentifikasi beresiko besar sebagai penyebab penyakit tulang belakang (low back pain)nyeri dan sakit akibat dari penanganan material secara manual yang cukup berat dan posisi tubuh yang tidak ergonomis.

Aktivitas penanganan material secara manual (Manual Material Handling) yang terdiri dari mengangkat, menurunkan, mendorong, menarik dan membawa merupakan sumber utama keluhan karyawan di industri. Aktivitas penanganan material secara manual yang tidak tepat dapat menimbulkan kerugian bahkan kecelakaan pada karyawan. Akibat yang ditimbulkan dari aktivitas penanganan material yang tidak tepat menyebabkan keluhan muskuloskeletal. Keluhan muskuloskeletal adalah keluhan pada bagian-bagian otot skeletal yang dirasakan oleh seseorang mulai dari keluhan yang sangat ringan sampai keluhan berat. Apabila otot menerima beban statis secara berulang dalam jangka waktu yang lama akan dapat menyebabkan keluhan berupa kerusakan pada sendi, ligamen dan tendon. Oleh sebab itu dalam melakukan aktivitas, karyawan perlu mengetahui sikap kerja yang berhubungan dengan lingkungan fisik (kerja) seperti faktor keamanan kerja, peralatan dan posisi kerja.Faktor-faktor tersebut perlu 
diperhatikan sehingga dalam mendesain ulang peralatan dan posisi kerja dapat tercipta kondisi yang ENASE (efektif, nyaman, aman, sehat dan efisien).Dalam melakukan pekerjaan terkadang menimbulkan kesalahan yang disebabkan oleh human factors sehingga dapat mempengaruhi produktivitas kerja karyawan. Seperti yang terjadi pada toko Mega Mas Elektronik, yang beraktivitas pada bidang penjualan barang elektronik.

Sikap kerja dalam mengangkat beban seperti yang dilakukan oleh karyawan "Mega Mas Elektronik Makassar" tergolong tidak ergonomis, seperti pada saat mengangkat beban (kulkas) seberat $35 \mathrm{~kg}$ dengan posisi tangan memanjang ke atas dan dengan punggung sebagai tumpuan beban yang apabila aktifitas ini dilakukan secara berulang dapat menyebabkan keluhan pada punggung dan bagian siku karyawan.

Untuk mengatasi keluhan yang dirasakan oleh karyawan, maka perlu dilakukan analisis apakah sikap kerja dan beban kerja yang ada pada saat ini direkomendasikan atau tidak. Sikap kerja yang kurang baik dapat menimbulkan terjadinya cedera pada pekerja yang pada akhirnya akan berdampak pada pencapaian target produksi yang telah ditetapkan oleh pihak perusahaan. Untuk mengetahui postur kerja tersebut berada pada level resiko cedera maka digunakan metode Rapid Upper Limb Assessment (RULA). RULA merupakan metode yang dikembangkan dalam bidang ergonomi dan dapat digunakan secara cepat untuk menilai posisi kerja atau postur kerja operator. Postur kerja yang diamati adalah leher, punggung, lengan, pergelangan tangan dan kaki seorang operator. Yang menjadi fokus analisis metode RULA adalah seluruh bagian tubuh pekerja. Melalui fokus terhadap keseluruhan postur tubuh ini, diharapkan bisa mengurangi potensi terjadinya musculoskeletal disorders pada tubuh perkerja. Sehingga metode RULA sangat sesuai dengan penelitian tentang postur kerja yang mencakup pergerakan tubuh.

\section{B. METODOLOGI PENELITIAN}

\section{Tempat dan Waktu Penelitian}

Penelitian ini dilaksanakan pada Toko Mega Mas Elektronik Makassar yang beralokasi di Jalan Bawakaraeng kota Makassar khususnya pada karyawan devisi kulkas. Penelitian ini dilakukan mulai dari bulan April sampai September 2016.

2. Alat dan Bahan

Alat dan bahan yang digunakan dalam penelitian ini adalah :

a. Meteran

Berfungsi untuk mengukur jarak atau panjang. Meteran juga berguna untuk mengukur sudut, membuat sudut siku-siku, dan juga dapat dipakai untuk membuat lingkaran. Pada ujung pita dilengkapi dengan pengait dan diberi magnet agar lebih mudah ketika sedang melakukan pengukuran, dan pita tidak lepas ketika mengukur.

b. Busur derajat

Busur derajat yang digunakan adalah merek butterfly untuk mengukur besar sudut setiap posisi atau postur tubuh pekerja pada saat bekerja.

c. Stopwatch

Stopwatch yang digunakan adalah stopwatch accusplit warna hitam Pro Survivor 601X untuk menghitung waktu/durasi pada saat bekerja.

d. Timbangan

Timbangan yang digunakan adalah timbangan digital bermerek Camry untuk menghitung berat beban pada saat bekerja dan berat badan pekerja.

e. Kamera

Kamera digunakan untuk mendokumentasikan posisi/postur pada saat bekerja. Kamera yang digunakan adalah kamera Canon EOS 500D dengan ukuran dimensi sebesar 128.8 x 97.5 x 75.3mm yang memiliki berat 475g. Canon EOS 500D dibekali dengan Recording System bertype Design rule for Camera File System 2.0 yang memiliki ukuran recording 
dengan beberapa bagian yang pertama bagian large dengan ukuran 17.90 megapixels, kedua ukuran Medium yang mempunyai ukuran 8.00 megapixels, kemudian small yang mempunyai ukuran 4.50 megapixels dan terakhir RAW yang mempunyai ukurn 17.90 megapixels.

3. Pengolahan Data

Pengolahan data terdiri dari :

a. Menggunakan data RULA untuk mengukur postur kerja dengan cara :

1) Membagi pengamatan tubuh operator kedalam 2 group, yaitu A yang terdiri atas leher (neck), kaki (leg), lengan atas (upper arm), lengan bawah (lower arm), pergelangan tangan (wrist), punggung (trunk), serta mengukur beban (load/force) dan skor aktivitas.

2) Menilai setiap postur kerja operator menggunakan Rapd Upper Limb Assesment (RULA) ke dalam skor A dan skor B.

3) Menentukan skor RULA dari hasil kombinasi perhitungan skor A dan skor B.

4) Menentukan action level dari postur kerja operator.

b. Menentukan postur kerja yang tidak ergonomis berdasarkan perhitungan skor RULA dan penentuan action level.

\section{HASIL DAN PEMBAHASAN}

1. Pengolahan data

Metode kerja yang dilakukan oleh pekerja pada devisi kulkas di Toko Mega Mas Elektronik dapat dilihat pada tabel 13.

Tabel 13. Metode kerja karyawan devisi kulkas pada Mega Mas Elektronik Makassar

\begin{tabular}{|l|l|c|l|c|}
\hline No. & \multicolumn{1}{|c|}{ Elemen Kegiatan } & Waktu (menit) & \multicolumn{1}{|c|}{ Sikap Kerja } & Kode \\
\hline 1. & Mengangkat kulkas & 00.57 & Jongkok & K1 \\
\hline 2. & Membawa kulkas ke gudang & 06.34 & $\begin{array}{l}\text { Berdiri dan } \\
\text { membungkuk }\end{array}$ & K2 \\
\hline 3. & $\begin{array}{l}\text { Meletakkan kulkas di } \\
\text { gudang }\end{array}$ & 01.23 & Berdiri & K3 \\
\hline
\end{tabular}

Sumber : Pegamatan pada Mega Mas Elektronik 2016

Penilaian postur kerja karyawan mengangkat kulkas dilakukan sesuai prosedur yang ada di bawah :

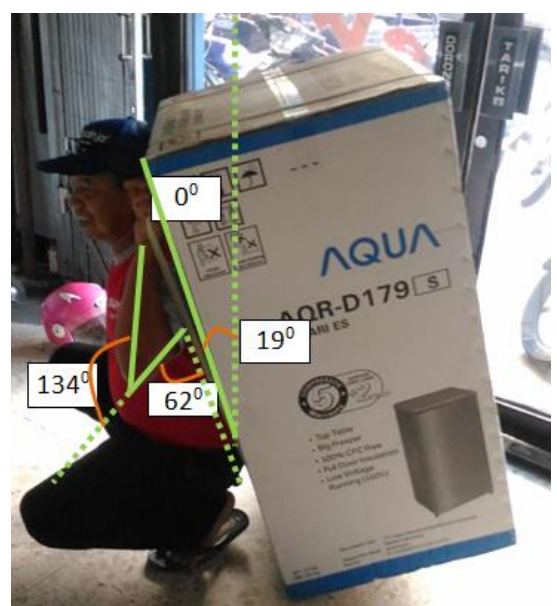

Gambar 3. Mengangkat kulkas(K1)

a. Group A

Kelompok A memperlihatkan postur tubuh bagian lengan atas, lengan bawah, pergelangan tangan. Kisaran lengan atas diukur dan diskor dengan dasar penemuan dari 
studi yang dilakukan oleh Tichauer, Caffin, Herberts et al, Hagbeg, Schuld et al dan Harms-Ringdahl dan Shuldt. (Kantana: 2010).

1) Lengan Atas

Pada gambar 3. diatas, lengan atas membentuk sudut $62^{\circ}$ sehingga mendapatkan skor 3 (tiga), karena bahu tidak terangkat dan lengan bawah tidak mendapatkan tekanan maka skor tidak ditambah 1 (satu) serta posisi tidak bersandar dan tangan tidak bertumpu maka skor tidak dikurangi 1 (satu). Jadi skor yang diperoleh dari posisi lengan atas adalah 3 (tiga).

2) Lengan Bawah

Pada gambar 3, lengan bawah membentuk sudut $134^{0}$ sehingga mendapatkan skor 2 (dua), karena lengan tidak bekerja menyilang didepan tubuh atau tidak berada di samping tubuh maka skor tidak ditambah 1 (satu). Jadi skor yang diperoleh posisi lengan bawah adalah 2 (dua).

3) Pergelangan Tangan

Pada gambar 3, telapak tangan netral mendapatkan skor 1 (satu), karena telapak tangan tidak mengalami tekukan pada deviasi ulnar dan radial maka skor tidak ditambah 1 (satu). Jadi skor yang diperoleh posisi pergelangan tangan adalah 1 (satu).

4) Tekukan

Pada gambar 3, telapak tangan tertekuk berputar pada posisi tengah sehingga mendapatkan skor1 (satu). Jadi skor yang diperoleh pada posisi tekukan telapak tangan adalah 1 (satu).

Tabel. 15. Pembobotan group A memindahkan piring kotor ke dalam baskom

\section{Pergelangan tangan}

\begin{tabular}{|c|c|c|c|c|c|c|c|c|c|}
\hline \multicolumn{2}{|l|}{ Tabel A } & \multicolumn{2}{|l|}{1} & \multicolumn{2}{|l|}{2} & \multicolumn{2}{|l|}{3} & \multicolumn{2}{|l|}{4} \\
\hline \multirow{2}{*}{$\begin{array}{l}\text { Lengan } \\
\text { Atas }\end{array}$} & \multirow{2}{*}{$\begin{array}{l}\text { Lengan } \\
\text { Bawah }\end{array}$} & \multicolumn{2}{|c|}{$\begin{array}{l}\text { Pergelangan } \\
\text { tangan menekuk }\end{array}$} & \multicolumn{2}{|c|}{$\begin{array}{l}\text { Pergelangan } \\
\text { tangan } \\
\text { menekuk }\end{array}$} & \multicolumn{2}{|c|}{$\begin{array}{l}\text { Pergelangan } \\
\text { tangan } \\
\text { menekuk }\end{array}$} & \multicolumn{2}{|c|}{$\begin{array}{l}\text { Pergelangan } \\
\text { tangan } \\
\text { menekuk }\end{array}$} \\
\hline & & 1 & 2 & 1 & 2 & 1 & 2 & 1 & 2 \\
\hline & 1 & 1 & 2 & 2 & 2 & 2 & 3 & 3 & 3 \\
\hline \multirow[t]{3}{*}{1} & 2 & 2 & 2 & 2 & 2 & 3 & 3 & 3 & 3 \\
\hline & 3 & 2 & 3 & 2 & 3 & 3 & 3 & 4 & 4 \\
\hline & 1 & 2 & 2 & 2 & 3 & 3 & 3 & 4 & 4 \\
\hline \multirow[t]{3}{*}{2} & 2 & 2 & 2 & 2 & 3 & 3 & 3 & 4 & 4 \\
\hline & 3 & 2 & 3 & 3 & 3 & 3 & 4 & 4 & 5 \\
\hline & 1 & 2 & 3 & 3 & 3 & 4 & 4 & 5 & 5 \\
\hline \multirow[t]{3}{*}{3} & 2 & 2 & 3 & 3 & 3 & 4 & 4 & 5 & 5 \\
\hline & 3 & 2 & 3 & 3 & 4 & 4 & 4 & 5 & 5 \\
\hline & 1 & 3 & 4 & 4 & 4 & 4 & 4 & 5 & 5 \\
\hline \multirow[t]{3}{*}{4} & 2 & 3 & 4 & 4 & 4 & 4 & 4 & 5 & 5 \\
\hline & 3 & 3 & 4 & 4 & 5 & 5 & 5 & 6 & 6 \\
\hline & 1 & 5 & 5 & 5 & 5 & 5 & 6 & 6 & 7 \\
\hline \multirow[t]{3}{*}{5} & 2 & 5 & 6 & 6 & 6 & 6 & 7 & 7 & 7 \\
\hline & 3 & 6 & 6 & 6 & 7 & 7 & 7 & 7 & 8 \\
\hline & 1 & 7 & 7 & 7 & 7 & 7 & 8 & 8 & 9 \\
\hline \multirow[t]{2}{*}{6} & 2 & 7 & 8 & 8 & 8 & 8 & 9 & 9 & 9 \\
\hline & 3 & 9 & 9 & 9 & 9 & 9 & 9 & 9 & 9 \\
\hline
\end{tabular}


b. Group B

1) Leher

Pada gambar 3, leher membentuk sudut $0^{0}$ sehingga mendapatkan skor 1 (satu), karena leher tidak menoleh kesamping kiri dan kanan serta leher tidak menekuk ke samping kiri dan kanan maka skor tidak ditambah 1(satu). Jadi skor yang diperoleh pada posisi leher adalah 1 (satu).

2) Punggung

Pada gambar 3, punggung membentuk $19^{0}$ sehingga mendapatkan skor 2 (dua). Jadi skor yang diperoleh pada posisi punggung adalah 2 (dua).

3) Kaki

Pada gambar 3, paha dan kaki saling mendukung dan seimbang sehingga mendapatkan skor 1 (satu). Jadi skor yang diporeleh pada posisi kaki adalah 1 (satu).

Tabel 16. Pembobotan group B memindahkan piring kotor ke baskom

\begin{tabular}{|c|c|c|c|c|c|c|c|c|c|c|c|c|}
\hline \multirow[t]{3}{*}{ Tabel B } & \multicolumn{12}{|c|}{ Batang Tubuh } \\
\hline & \multicolumn{2}{|l|}{1} & \multicolumn{2}{|l|}{2} & \multicolumn{2}{|l|}{3} & \multicolumn{2}{|l|}{4} & \multicolumn{2}{|c|}{5} & \multicolumn{2}{|l|}{6} \\
\hline & \multicolumn{2}{|c|}{ Kaki } & \multicolumn{2}{|c|}{ Kaki } & \multicolumn{2}{|c|}{ Kaki } & \multicolumn{2}{|c|}{ Kaki } & \multicolumn{2}{|c|}{ Kaki } & \multicolumn{2}{|c|}{ Kaki } \\
\hline Leher & 1 & 2 & 1 & 2 & 1 & 2 & 1 & 2 & 1 & 2 & 1 & 2 \\
\hline 1 & 1 & 3 & 2 & 3 & 3 & 4 & 5 & 5 & 6 & 6 & 7 & 7 \\
\hline 2 & 2 & 3 & 2 & 3 & 4 & 5 & 5 & 5 & 6 & 7 & 7 & 7 \\
\hline 3 & 3 & 3 & 3 & 4 & 4 & 5 & 5 & 6 & 6 & 7 & 7 & 7 \\
\hline 4 & 5 & 5 & 5 & 6 & 6 & 7 & 7 & 7 & 7 & 7 & 8 & 8 \\
\hline 5 & 7 & 7 & 7 & 7 & 7 & 8 & 8 & 8 & 8 & 8 & 8 & 8 \\
\hline 6 & 8 & 8 & 8 & 8 & 8 & 8 & 8 & 9 & 9 & 9 & 9 & 9 \\
\hline
\end{tabular}

c. Grand Score

Tahap grand score bertujuan untuk menggabungkan Skor C dan Skor D menjadi suatu grand score tunggal yang dapat memberikan panduan terhadap prioritas penyelidikan/investigasi berikutnya. Tiap kemungkinan kombinasi Skor C dan Skor D telah diberikan peringkat, yang disebut grand score dari 1-7 berdasarkan estimasi resiko cidera yang berkaitan dengan pembebanan muskuloskeletal. Grand score dapat diformulasikan dengan rumus sebagai berikut:

Score $\mathrm{C}=$ Score $\mathrm{A}+$ muscle use score dan force/load score grup $\mathrm{A}$

Score $\mathrm{D}=$ Score $\mathrm{B}+$ muscle use score dan force/load score grup $\mathrm{B}$

1) Penggunaan otot

Pada penelitian postur tubuh yang telah dilakukan tidak adanya penggunaan otot pada penelitian ini sehingga mendapat skor 0 .

2) Gaya atau pembebanan

Berdasarkan penelitian yang telah di lakukan beban kerja lebih dari $10 \mathrm{~kg}$ dan mengalami pengulangan maka mendapatkan skor 3 .

Score $\mathrm{C}=$ score group $\mathrm{A}+$ penggunaan otot + pembebanan

$$
\begin{aligned}
& =2+0+3 \\
& =5
\end{aligned}
$$

Score $\mathrm{D}=$ score group $\mathrm{B}+$ penggunaan otot + pembebanan

$$
=2+0+3
$$$$
=5
$$

Tabel 17. Grand Score memindahkan piring ke baskom

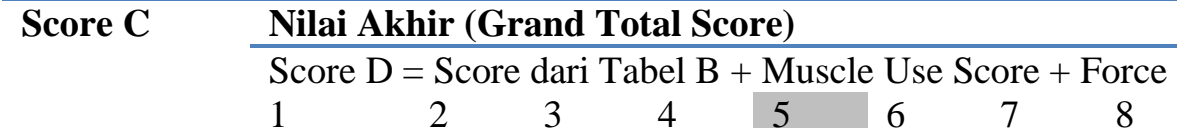




\begin{tabular}{llllllllll}
\hline $\mathbf{1}$ & 1 & 2 & 3 & 3 & 4 & 5 & 5 & 5 & 5 \\
$\mathbf{2}$ & 2 & 2 & 3 & 4 & 4 & 5 & 5 & 5 & 5 \\
$\mathbf{3}$ & 3 & 3 & 3 & 4 & 4 & 5 & 6 & 6 & 6 \\
$\mathbf{4}$ & 3 & 3 & 3 & 4 & 5 & 6 & 6 & 6 & 6 \\
$\mathbf{5}$ & 4 & 4 & 4 & 5 & 6 & 7 & 7 & 7 & 7 \\
$\mathbf{6}$ & 4 & 4 & 5 & 6 & 6 & 7 & 7 & 7 & 7 \\
$\mathbf{7}$ & 5 & 5 & 6 & 6 & 7 & 7 & 7 & 7 & 7 \\
$\mathbf{8}$ & 5 & 5 & 6 & 7 & 7 & 7 & 7 & 7 & 7 \\
$\mathbf{9}$ & 5 & 5 & 6 & 7 & 7 & 7 & 7 & 7 & 7 \\
\hline
\end{tabular}

Gambar 4. adalah gambar postur kerja keryawan membawa kulkas(K2), gambar 5. adalah gambar postur kerja karyawan meletakkan kulkas di gudang(K3).

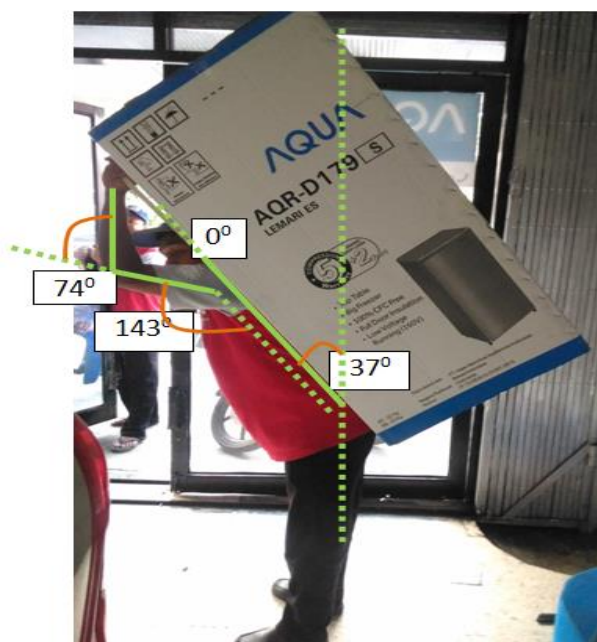

Gambar 4. Membawa kulkas

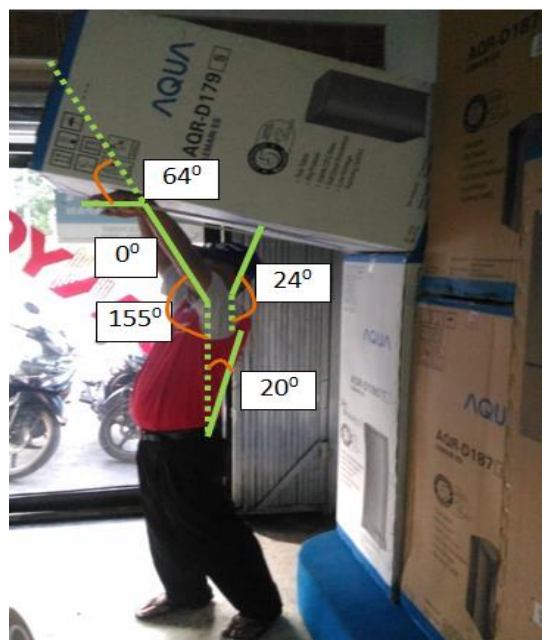

Gambar 5. Meletakkan kulkas di gudang

Seperti yang telah dilakukan pada kegiatan memindahkan piring kotor maka dapat di tabulasi seperti terlihat pada tabel 18 .

Tabel 18. Skor penilaian postur kerja

\begin{tabular}{|c|c|c|c|c|l|}
\hline $\begin{array}{c}\text { Kode } \\
\text { Kegiatan }\end{array}$ & $\begin{array}{c}\text { Skor } \\
\text { Group A }\end{array}$ & $\begin{array}{c}\text { Skor } \\
\text { Group B }\end{array}$ & $\begin{array}{c}\text { Grand } \\
\text { Score }\end{array}$ & $\begin{array}{c}\text { Level } \\
\text { Kegiatan }\end{array}$ & \multicolumn{1}{|c|}{ Saran Tindakan } \\
\hline K1 & 4 & 5 & 7 & 3 & $\begin{array}{l}\text { Investigasi dan } \\
\text { perubahan postur kerja } \\
\text { harus dilakukan } \\
\text { secepatnya. }\end{array}$ \\
\hline K2 & 3 & 6 & 7 & 4 & $\begin{array}{l}\text { Investigasi dan } \\
\text { perubahan harus } \\
\text { dilakukan dengan } \\
\text { segera. }\end{array}$ \\
\hline K3 & 4 & 5 & 7 & 4 & $\begin{array}{l}\text { Investigasi dan } \\
\text { perubahan harus } \\
\text { dilakukan dengan } \\
\text { segera. }\end{array}$ \\
\hline
\end{tabular}

2. Analisa Masalah

Dari hasil pengolahan data postur kerja karyawan Mega Mas Elektronik pada bagian mengangkat kulkas dengan menggunakan metode Rapid Upper Limb Assessment (RULA), maka dilakukan analisa terhadap permasalahn yang ada, yaitu :

a. Penilaian postur kerja karyawan mengangkat kulkas 
Penilaian pembobotan Group A berdasarkan table 15. dimana nilai lengan atas adalah 3 , lengan bawah 2, pergelangan tangan 1 dan pergelangan tangan menekuk adalah 1 maka skor pembobotan adalah 2 (dua). Berdasarkan table 16. dimana score leher adalah 1, punggung 2, serta kaki 1 maka skor pembobotan pada Group B adalah 2 (dua).

Skor akhir untuk elemen kegiatan mengangkat kulkas berdasarkan tabel 17. adalah 6 (enam). Berdasarkan skor tersebut maka level resiko dari aktivitas tersebut berada pada kategori level 3 yang berarti investigasi dan perubahan postur kerja harus dilakukan secepatnya.

b. Penilaian postur kerja karyawan membawa kulkas ke gudang

Berdasarkan gambar 4. dimana nilai lengan atas adalah 4, lengan bawah 1, pergelangan tangan 1 dan pergelangan tangan menekuk adalah 1 maka skor pembobotan pada Group A adalah 3 (tiga). Sedangkan penilaian Group B dimana score leher adalah 4, punggung 3, serta kaki 1 maka skor pembobotan pada Group B adalah 6 (enam).

Skor akhir untuk elemen kegiatan kulkas ke gudang berdasarkan tabel 18. adalah sebesar 7 (tujuh). Berdasarkan skor tersebut maka level resiko dari aktivitas tersebut berada pada kategori level 4 yang mengindikasikan bahwa investigasi dan perubahan harus dilakukan dengan segera.

c. Penilaian postur kerja karyawan meletakkan kulkas di gudang

Penilaian pembobotan Group A Berdasarkan table 18. dimana nilai lengan atas adalah 4, lengan bawah 1, pergelangan tangan 3 dan pergelangan tangan menekuk adalah 1 maka nilai skor adalah 4 (empat). Sedangakan pembobotan Group B berdasarkan table 18 . dimana score leher adalah 4, punggung 2, serta kaki 1 maka nilai skor adalah 5 (lima).

Skor akhir untuk elemen kegiatan membawa baskom berisi piring kotor berdasarkan tabel 18. adalah sebesar 7 (tujuh). Berdasarkan skor tersebut maka level resiko dari aktivitas tersebut berada pada kategori level 4 yang mengindikasikan bahwa investigasi dan perubahan harus dilakukan dengan segera.

3. Usulan Pemecahan Masalah

Dari masalah-masalah yang ditemui pada bagian mengangkat kulkas pada Toko Mega Mas Elektronik Makassar maka diusulkan alternatif pemecahan masalah yaitu :

a. Menggunakan troli pada saat mengangkat kulkas.

b. Menggunakan troli pada saat membawa kulkas ke gudang.

c. Menggunakan troli hidrolic untuk meletakkan kulkas di gudang.

Analisis postur kerja setelah menggunakan troli pada saat mengangkat, membawa, dan meletakkan kulkas di gudang seperti terlihat pada gambar di bawah ini.

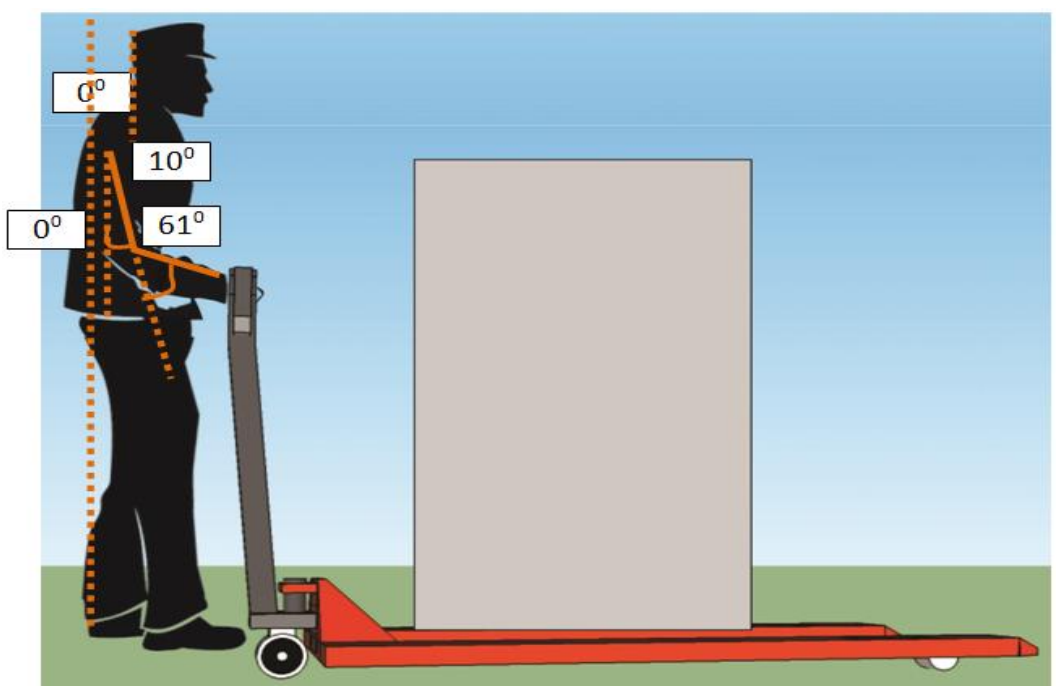

Gambar 6. Usulan postur kerja membawa kulkas 


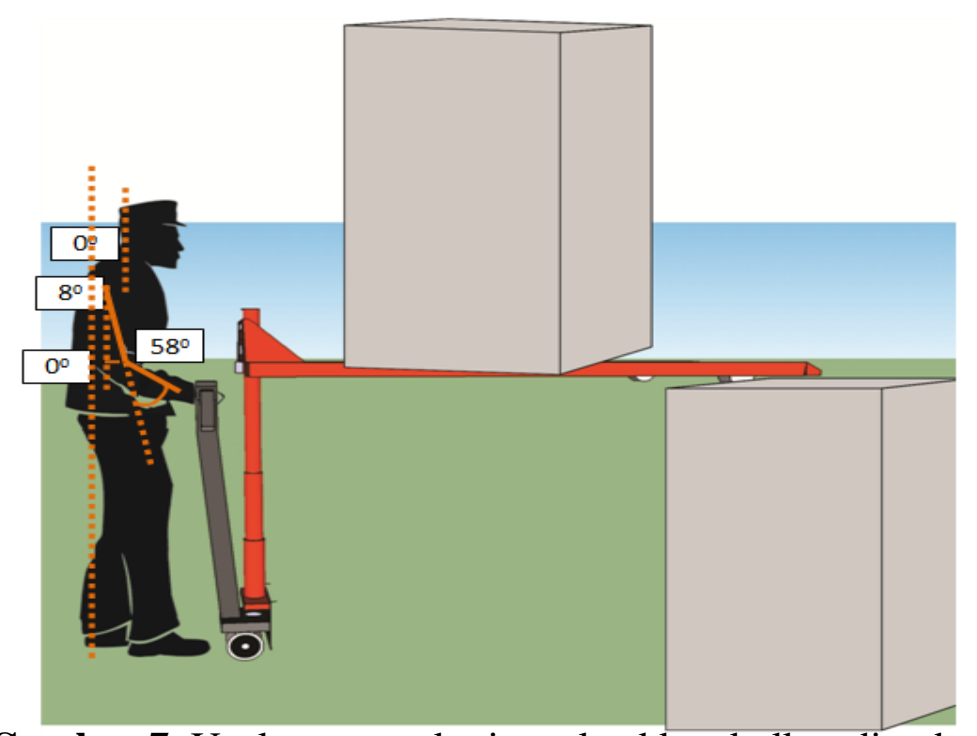

Gambar 7. Usulan postur kerja meletakkan kulkas digudang

Berdasarkan gambar usulan diatas maka dilakukan pengolahan data seperti pada kegiatan mengangkat kulkas sehingga di dapatkan tabulasi untuk usulan kegiatan membawa kulkas, dan usulan kegiatan meletakkan kulkas di gudang seperti terlihat pada tabel 19.

Tabel 19. Skor penilaian untuk kegiatan usulan perbaikan postur kerja

\begin{tabular}{|c|c|c|c|c|c|}
\hline Kegiatan & $\begin{array}{c}\text { Skor } \\
\text { Group A }\end{array}$ & $\begin{array}{c}\text { Skor } \\
\text { Group B }\end{array}$ & $\begin{array}{c}\text { Grand } \\
\text { Score }\end{array}$ & $\begin{array}{c}\text { Level } \\
\text { Kegiatan }\end{array}$ & Saran Tindakan \\
\hline Usulan K2 & 1 & 1 & 2 & 1 & $\begin{array}{l}\text { Postur kerja dapat diterima } \\
\text { dan tidak memerlukan } \\
\text { perbaikan untuk jangka } \\
\text { waktu yang lama. }\end{array}$ \\
\hline Usula K3 & 1 & 2 & 2 & 1 & $\begin{array}{l}\text { Postur kerja dapat diterima } \\
\text { dan tidak memerlukan } \\
\text { perbaikan untuk jangka } \\
\text { waktu yang lama. }\end{array}$ \\
\hline
\end{tabular}

Setelah dilakukan usulan penambahan troli pada saat pekerja memindahkan kulkas ke gudang maka kegiatan mengangkat kulkas seperti terlihat pada gambar 3 tidak perlu dilakukan oleh pekerja.

\section{E. PENUTUP}

1. Kesimpilan

Berdasarkan pengolahan data dan pembahasan analisa pada penelitian ini, maka dapat diambil kesimpulan sebagai berikut : 
a. Berdasarkan hasil pengolahan data dengan metode RULA maka dapat disimpulkan bahwa postur kerja pada bagian mengangkat kulkas berada pada level resiko 3, yang mengindikasi investigasi dan perubahan postur kerja harus dilakukan secepatnya. Sedangkan kegiatan membawa dan meletakkan kulkas digudang berada pada level resiko 4 yang berarti investigasi dan perubahan postur kerja harus dilakukan segera.

b. Setelah dilakukan rancangan usulan postur kerja dengan menggunakan troli pada kegiatan memindahkan kulkas ke dalam gudang mendapat grang score 2 yang berarti berada di level 1 berarti postur kerja dapat diterima dan tidak memerlukan perbaikan untuk jangka waktu yang lama.

2. Saran

Saran yang dapat diberikan kepada pihak Mega Mas Elektronik Makassar :

a. Penambahan fasilitas kerja berupa troli, hal ini dapat mengefisienkan waktu kerja serta membantu pekerja saat membawa dan meletakkan kulkas digudang.

b. Perbaikan metode kerja untuk mengurangi kelelahan dan meningkatkan produktivitas.

\section{DAFTAR PUSTAKA}

Budhiman, M, A. Analisis Penilaian Tingkat Resiko Ergonomi pada Pekerja Konstruksi Proyek Ruko Graha Depok. Jakarta : UIN Syarif Hidayatullah. 2015.

Chaffin, D.B., and Anderson, G.B. 1991 Occupational Biomechanical. New York: John Wiley \& Sons.

Hastomo, Endri. Perancangan Ulang Alat Bantu Penghitug DOP berdasarkan Antropometri dengan Analisis RULA. Surakarta : Universitas Sebelas Maret. 2010.

Joe. Dasar Pemahaman Ergonomi. joe-proudly-present. blogspot. co. id/ 2011/ 11/ ergonomi.html. 25 April 2016.

Kantana Trimunggara. 2010. Faktor - Faktor yang Mempengaruhi Keluhan Low Back Pain pada Kegiatan Mengemudi Tim Ekspedisi Pt Enseval Putera Megatrading Jakarta Tahun 2010. Jakarta : Universitas Islam Negeri Syarif Hidayatullah.

Nurmianto, Eko. 1996. Ergonomi Konsep Dasar dan Aplikasinya. Surabaya:Guna Widya.

Nurmianto, Eko. Ergonomi Konsep Dasar dan Aplikasinya. Surabaya: Intitut Teknologi Sepuluh November. 2004.

Pangaribuan, D, M. Analisa Postur Kerja dengan Metode RULA pada Pegawai Bagian Pelayanan Perpustakaan USU Medan. Medan: Universitas Sumatera Utara. 2009.

Santoso, G. Ergonomi (Manusia, Peralatan dan Lingkungan). Jakarta: Prestasi Pustaka. 2004.

Sunarso. Perancangan Troli sebagai Alat Bantu Angkut Galon Air Mineral dengan Pendekatan Anthropometri. Surakarta : Universitas Sebeas Maret. 2010.

Sutalaksana, I.Z. 1979. Teknik Tata Cara Kerja. Laboratorium Tata Cara Kerja dan Ergonomi Dept. Teknik Industri- ITB.

Sutalaksana, Iftikar Z. Teknik Tata Cara Kerja. Bandung: Institut Teknologi Bandung. 1979. Wignjosoebroto. 2003, Sritomo. Ergonomi Studi Gerak Dan Waktu. Surabaya : Guna Widya. 